\title{
Jurnal Olahraga \\ Perbandingan Model Pendekatan Taktis dan Model Pembelajaran Kooperatif terhadap Jumlah Waktu Aktif Belajar (JWAB) dalam Pembelajaran Permainan Bolabasket
}

\begin{tabular}{|c|c|}
\hline & $\begin{array}{l}\text { hammad Hasbiyal Fahri }{ }^{\mathbf{1}} \text {, Tite Juliantine } \\
{ }^{1,2} \text { STKIP Pasundan, Indonesia }\end{array}$ \\
\hline Info Artikel & Abstrak \\
\hline $\begin{array}{l}\text { Sejarah Artikel: } \\
\text { Diterima Agustus } 2016 \\
\text { Disetujui Oktober } 2016 \\
\text { Dipublikasikan Oktober } 2016\end{array}$ & $\begin{array}{l}\text { Tujuan penelitian ini adalah untuk mengetahui pengaruh model } \\
\text { pendekatan taktis dan model pembelajaran kooperatif terhadap } \\
\text { jumlah waktu aktif belajar (JWAB) siswa dalam pembelajaran } \\
\text { permainan bolabasket. Metode penelitian yang digunakan yaitu } \\
\text { metode eksperimen. Populasi dalam penelitian ini sebanyak } 300 \\
\text { siswa dan sampel sebanyak } 40 \text { siswa. Pengambilan sampel } \\
\text { menggunakan teknik purposive sampling. Desain penelitian } \\
\text { menggunakan one group pretest-posttest design. Instrumen } \\
\text { penelitian dalam penelitian ini menggunakan instrumen penilaian } \\
\text { penampilan mengajar penjas. Data mentah menunjukan adanya } \\
\text { perbedaan rata-rata antara kelompok model pendekatan taktis } \\
\text { dengan kelompok model pembelajaran kooperatif terhadap jumlah } \\
\text { waktu aktif belajar. Hasil pengolahan data dan pengujian hipotesis } \\
\text { menunjukan peningkatan jumlah waktu aktif belajar siswa SMP } \\
\text { Negeri } 1 \text { Plered. Dari hasil pengolahan dan analisis data diperoleh } \\
\text { kesimpulan bahwa model pendekatan taktis memberikan pengaruh } \\
\text { yang lebih signifikan dibandingkan dengan model pembelajaran } \\
\text { kooperatif terhadap jumlah waktu aktif belajar di SMP Negeri } 1 \\
\text { Plered. }\end{array}$ \\
\hline
\end{tabular}

Abstract

The purpose of this study was to determine the effect of tactical approach models and cooperative learning models on the amount of active learning time (JWAB) students in learning basketball games. The research method used is the experimental method. The population in this study were 300 students and a sample of 40 students. Sampling using a purposive sampling technique. The research design uses one group pretest-posttest design. The research instrument in this study used the physical teaching performance assessment instrument. Raw data shows an average difference between the tactical approach model group and the cooperative learning model group to the amount of active learning time. The results of data processing and hypothesis testing show an increase in the amount of active learning time for students of SMP Negeri 1 Plered. From the results of data processing and analysis, it can be concluded that the tactical approach model gives a more significant effect compared to 
the cooperative learning model on the amount of active learning time in Plered 1 Junior High School.

(C) 2016 Muhammad Hasbiyal Fahri, Tite Juliantine

Under the license CC BY-SA 4.0

Alamat korespondensi:

E-mail:

\section{PENDAHULUAN}

Proses belajar megajar merupakan inti dari proses pendidikan secara keseluruhan dengan guru sebagai pemegang peranan utama. Peristiwa belajar mengajar banyak berakar pada berbagai pandangan dan konsep ilmu kependidikan. Oleh karena itu perwujudan proses belajar mengajar dapat terjadi dalam berbagai model. Bruce Joyce dan Marshal Weil mengemukakan 22 model mengajar yang di kelompokan ke dalam 4 hal, yaitu : Proses informasi, perkembangan pribadi, interaksi sosial dan modifikasi tingkah laku (Joyce \& Weil, Models of Teaching, 1980).

Dalam pembelajaran, seorang guru harus dapat menerapkan berbagai model pembelajaran dengan tujuan agar proses belajar mengajar lebih terencana dan menjadi bervariasi serta tidak membosankan. Dalam konteks pembelajaran, Joyce dan Weil (Winataputra, 2001:115) mendefinisikan model sebagai kerangka konseptual yang digunakan sebagai pedoman dalam melakukan suatu kegiatan. Jadi model pembelajaran adalah kerangka konseptual yang melukiskan prosedur yang sistematis dalam mengorganisasikan pengalaman belajar untuk mencapai tujuan belajar tertentu.

Model-model pembelajaran yang dapat diterapkan dalam pembelajaran pendidikan jasmani menurut Metzler (2000:159) menjelaskan bahwa :

There are seven instruction models that have shown to be effective in teaching physical education : Direct Instruction Model, Personalized for Instruction
Model, Cooperative Learning Model, The Sport Education Model, Peer Teaching Model, Inquiry Teaching Model and The Tactical Games Model.

Jadi menurut Metzler terdapat tujuh model pembelajaran dalam pendidikan jasmani yaitu : (1) Model Pembelajaran Langsung (2) Model Pembelajaran Personal (3) Model Pembelajaran Kerjasama (4) Model Pembelajaran Pendidikan Olahraga (5) Model Pembelajaran Kelompok (6) Model Pembelajaran Inkuiri (7) Model Pembelajaran Taktis.

Dari tujuh model pembelajaran tersebut, penulis mencoba mengkaji dua model pembelajaran yaitu Model Pembelajaran Taktis (The Tactical Approach Model) dan Model Pembelajaran Kerjasama (Cooperative Learning Model) yang akan diterapkan pada pembelajaran permainan bolabasket untuk melihat Jumlah Waktu Aktif Belajar. Adapun alasan mengapa kedua model tersebut diterapkan pada pembelajaran permainan bolabasket untuk melihat jumlah waktu aktif belajar adalah pada saat proses pembelajaran berlangsung dirasakan siswa kurang begitu aktif dikarenakan siswa kurang berpartisipasi secara aktif dalam setiap kegiatan dimana siswa banyak menunggu instruksi yang diberikan oleh guru (teacher centre) dan penerapan model pembelajaran langsung yang merupakan salah satu sebab mengapa jumlah waktu aktif belajar siswa rendah.

Dari pemaparan di atas, penulis ingin menerapkan kedua model pembelajaran taktis dan model pembelajaran kooperatif terhadap jumlah waktu aktif belajar dalam aktifitas 
pembelajaran permainan bolabasket. Adapun alasan mengapa kedua model ini menjadi pilihan untuk dikaji oleh penulis, karena penulis ingin mencoba membandingkan apakah ada perbedaan dalam hal jumlah waktu aktif belajar dari penerapan kedua model pembelajaran tersebut.

Oleh karena itu dalam kesempatan ini penulis tertarik untuk meneliti dengan mengambil judul, "Perbandingan Model Pendekatan Taktis Dan Model Pembelajaran Kooperatif Terhadap Jumlah Waktu Aktif Belajar (JWAB) Dalam Pembelajaran Permainan Bolabasket".

\section{METODE}

Metode yang digunakan dalam penelitian ini adalah metode eksperimen dengan desain one group pretest-posttest design.

Populasi dalam penelitian ini adalah siswa SMP Negeri 1 Plered Purwakarta, kelas VIII. Sampel dipilih dengan menggunakan teknik purposive sampling. Sampel yang diambil dengan menggunakan teknik ini adalah sampel yang memiliki kriteria yaitu siswa kelas VIII yang mengikuti ekstrakurikuler basket, merupakan tingkat pemula dan berjenis kelamin laki-laki.

Dalam penelitian ini dibutuhkan dua kelompok sampel. Setelah dilakukan teknik purposive sampling terhadap kelompokkelompok kelas, dihasilkan dua kelompok sampel yaitu kelompok 1 (yang diberikan perlakuan model pendekatan taktis) dan kelompok 2 (yang diberikan perlakuan model pembelajaran kooperatif). Jumlah pertemuan dalam perlakuan sebanyak 12 kali pertemuan. Sebelumnya kedua kelompok tersebut terlebih dahulu diberikan pretest dengan tujuan untuk mengetahui kemampuan awal sampel sebelum diberikan perlakuan. Setelah skor pretest diperoleh. Berdasarkan hasil penghitungan, diperoleh skor rata-rata yaitu tes awal kelompok 130,05 dan tes akhir kelompok 1 59,90, sedangkan tes awal kelompok 2 28,15 dan tes akhir kelompok 2 57,95 .

Instrumen untuk mengetahui jumlah waktu aktif belajar ini menggunakan instrumen penilaian penampilan mengajar penjas. Instrumen tersebut merupakan instrumen yang sudah baku dimana instrumen tersebut merupakan metode observasi sistematis dengan menggunakan teknik duration recording.

Observasi menurut Sugiyono (2011:145) adalah "merupakan suatu proses yang kompleks yang tersusun dari berbagai proses biologis dan psikologis".

Hal-hal yang diperlukan dalam observasi pada penelitian ini adalah sebagai berikut :

1. Tes

a. Pretest

Pretest digunakan untuk mengukur jumlah waktu aktif belajar siswa pada saat pembelajaran bolabasket di awal penelitian.

b. Posttest

Posttest digunakan untuk mengukur jumlah waktu aktif belajar siswa pada saat pembelajaran bolabasket setelah diberikan treatment. Treatment yang diberikan yaitu melalui model pendekatan taktis dan model pembelajaran kooperatif dalam pembelajaran bolabasket.

2. Format Lembar Observasi

Untuk mengetahui bagaimana penerapan model pendekatan taktis dan model pembelajaran kooperatif terhadap jumlah waktu aktif belajar, penulis akan menggunakan instrumen penelitian penampilan mengajar dengan menggunakan metode observasi sistematis melalui teknik duration recording, dimana teknik duration recording ini digunakan untuk memotret keterampilan guru pendidikan jasmani dalam mengajar, terutama yang berhubungan erat dengan penggunaan waktu yang dihabiskan selama pembelajaran. Adapun Suherman (2009:115) mengungkapkan ada empat kategori aktivitas dalam proses pembelajaran 
pendidikan jasmani, antara lain sebagai berikut : Manajemen (M), Aktivitas Belajar (A), Intructional (I), dan Waiting (W).

Setelah melihat pemaparan di atas, maka peneliti akan mengaplikasikannya dalam pembelajaran bolabasket di SMP Negeri 1 Plered Purwakarta. Penulis merujuk pada format menggabungkan dua tujuan yaitu untuk mengetahui pemanfaatan waktu aktif belajar gerak dan proporsi jumlah siswa yang belajar gerak. Maka format lembar observasinya adalah sebagai berikut :

Tabel 1. Format Lembar Observasi

\begin{tabular}{|c|c|c|c|}
\hline No & Stopwatch & Alokasi fokus & $\begin{array}{c}\text { Jumlah siswa } \\
\text { fokus }\end{array}$ \\
\hline 1 & $0: 01: 00$ & & \\
\hline 2 & $0: 02: 00$ & & \\
\hline 3 & $0: 03: 00$ & & \\
\hline Dst & & & \\
\hline
\end{tabular}

Teknik analisis data untuk menguji hipotesis dalam penelitian ini menggunakan uji t yaitu kesamaan dua rata-rata dengan uji satu pihak.

\section{HASIL DAN PEMBAHASAN}

Data yang dikumpulkan melalui proses pengukuran, selanjutnya diolah dan dianalisis dengan menggunakan pendekatan statistik. Data yang dianalisis dalam penelitian ini adalah data hasil jumlah waktu aktif belajar. Penjelasan mengenai persentase hasil tes awal jumlah waktu aktif belajar siswa untuk kelompok 1 (kelompok model pendekatan taktis) adalah untuk waktu aktivitas belajar (A) memperoleh persentase 38,125\%. Sedangkan hasil tes akhir kelompok 1 setelah diberikan treatment adalah untuk waktu aktivitas belajar (A) mengalami peningkatan memperoleh persentase $75,5 \%$, ini menunjukan bahwa model pendekatan taktis berpengaruh terhadap jumlah waktu aktif belajar dalam pembelajaran permainan bolabasket. Adapun persentase hasil tes awal jumlah waktu aktif belajar siswa untuk kelompok 2 (kelompok model pembelajaran kooperatif) adalah untuk waktu aktivitas belajar (A) memperoleh persentase 35,18\%. Sedangkan hasil tes akhir kelompok 2 setelah diberikan treatment adalah untuk waktu aktivitas belajar (A) memperoleh persentase $65,43 \%$, ini menunjukan bahwa model pembelajaran kooperatif berpengaruh terhadap jumlah waktu aktif belajar dalam pembelajaran permainan bolabasket.

Dari pemaparan diatas terlihat bahwa hasil tes akhir model pendekatan taktis memiliki persentase $75,5 \%$ sedangkan model pembelajaran kooperatif memiliki persentase $65,43 \%$, ini menunjukan bahwa model pendekatan taktis berpengaruh secara signifikan dibandingkan dengan model pembelajaran kooperatif terhadap jumlah waktu aktif belajar dalam pembelajaran permainan bolabasket.

Data hasil penghitungan rata-rata dan simpangan baku dari kelompok 1 dengan model pendekatan taktis adalah sebagai berikut :

Tabel 2. Data Hasil Penghitungan Ratarata dan Simpangan Baku Tes Awal dan Tes Akhir Kelompok 1

\begin{tabular}{|c|c|c|c|}
\hline Kelompok & Periode & $\begin{array}{c}\text { Rata- } \\
\text { rata }\end{array}$ & $\begin{array}{c}\text { Simpangan } \\
\text { Baku }\end{array}$ \\
\hline Kelompok \\
1 \\
$\begin{array}{c}\text { Kelompok } \\
\text { Model } \\
\text { Pendekatan } \\
\text { Taktis) }\end{array}$ & $\begin{array}{c}\text { Tes Awal (tanpa } \\
\text { perlakuan) } \\
\text { menghir (dengan } \\
\text { Model Pendekatan } \\
\text { Taktis) }\end{array}$ & 30,05 & 2,40 \\
\cline { 2 - 4 } & Selisih & 29,85 & 0,52 \\
\hline
\end{tabular}

Tabel 2 menunjukkan bahwa rata-rata tes awal sebesar 30,05 dengan simpangan baku 2,40 dan rata-rata tes akhir pembelajaran dengan model pendekatan taktis sebesar 59,90 dengan simpangan baku 2,92, sedangkan rata-rata selisihnya sebesar 29,85 dengan simpangan baku 0,46. Sedangkan untuk data dari kelompok 2 dengan model pembelajaran kooperatif adalah sebagai berikut 
Tabel 3. Data Hasil Penghitungan Rata-rata dan Simpangan Baku Tes Awal dan Tes Akhir Kelompok 2

\begin{tabular}{|c|c|c|c|c|}
\hline Kelompok & Periode Tes & $\mathbf{L}_{\mathbf{O}}$ & $\mathbf{L}_{\text {tabel }}$ & Kesimpulan \\
\hline & $\begin{array}{c}\text { Tes Awal } \\
\text { (tanpa } \\
\text { perlakuan) }\end{array}$ & 0,148 & 0,190 & Normal \\
$\begin{array}{c}\text { Kelompok 1 } \\
\text { (Kelompok } \\
\text { Model } \\
\begin{array}{c}\text { Pendekatan } \\
\text { Taktis) }\end{array}\end{array}$ & $\begin{array}{c}\text { Tes Akhir } \\
\text { (dengan } \\
\text { menggunakan } \\
\text { Model } \\
\text { Pendekatan } \\
\text { Taktis) }\end{array}$ & 0,114 & 0,190 & Normal \\
\hline
\end{tabular}

Tabel 3 menunjukkan bahwa rata-rata tes awal sebesar 28,15 dengan simpangan baku 2,74 dan rata-rata tes akhir pembelajaran dengan model pembelajaran kooperatif sebesar 57,95 dengan simpangan baku 2,84, sedangkan rata-rata selisihnya sebesar 29,80 dengan simpangan baku 0,10.

Setelah nilai rata-rata dan simpangan baku diketahui, maka langkah selanjutnya adalah melakukan uji normalitas dari data hasil tes tersebut dengan menggunakan uji liliefors. Adapun hasil dari pengujian tersebut untuk kelompok 1 dapat dilihat dalam Tabel 4.3 sebagai berikut :

Tabel 4. Data Hasil Pengujian Normalitas Liliefors Tes Awal dan Tes Akhir Kelompok 1

\begin{tabular}{|c|c|c|c|}
\hline Kelompok & Periode & $\begin{array}{c}\text { Rata- } \\
\text { rata }\end{array}$ & $\begin{array}{c}\text { Simpangan } \\
\text { Baku }\end{array}$ \\
\hline \multirow{3}{*}{$\begin{array}{c}\text { Kelompok } 2 \\
\text { (Kelompok } \\
\text { Model } \\
\text { Pembelajaran } \\
\text { Kooperatif) }\end{array}$} & $\begin{array}{c}\text { Tes Awal } \\
\text { (tanpa } \\
\text { perlakuan) }\end{array}$ & 28,15 & 2,74 \\
\hline & $\begin{array}{c}\text { Tes Akhir } \\
\text { (dengan } \\
\text { menggunakan } \\
\text { Model } \\
\text { Pembelajaran } \\
\text { Kooperatif) }\end{array}$ & 57,95 & 2,84 \\
\hline & Selisih & 29,80 & 0,10 \\
\hline
\end{tabular}

Berdasarkan tabel atas dapat diketahui bahwa nilai $\mathrm{L}_{\text {tabel }}$ dari daftar $=0,190$. Sedangkan nilai $\mathrm{L}_{O}$ tes awal sebesar $=0,148$ dan $\mathrm{L}_{\mathrm{O}}$ tes akhir sebesar $=0,114$. Kriteria pengujiannya adalah tolak hipotesisnya nol jika $\mathrm{L}_{\mathrm{O}}$ yang diperoleh dari data pengamatan melebihi $\mathrm{L}_{\text {tabel. }}$. Dalam hal lainnya hipotesis nol diterima. Dengan demikian data tes awal dan tes akhir berdistribusi normal, karena nilai $\mathrm{L}_{\mathrm{O}}$ lebih kecil dari nilai $\mathrm{L}_{\text {tabel. }}$.

Sedangkan hasil dari uji normalitas untuk kelompok 2 dapat dilihat dalam Tabel 5 sebagai berikut :

Tabel 5. Data Hasil Pengujian Normalitas Liliefors Tes Awal dan Tes Akhir Kelompok 2

\begin{tabular}{|c|c|c|c|c|}
\hline Kelompok & Periode Tes & $\mathbf{L}_{\mathbf{O}}$ & $\mathbf{L}_{\text {tabel }}$ & Kesimpulan \\
\hline Kelompok 2 & $\begin{array}{c}\text { Tes Awal } \\
\text { (tanpa } \\
\text { perlakuan) }\end{array}$ & 0,128 & 0,190 & Normal \\
\cline { 2 - 5 } $\begin{array}{c}\text { Telompok Akhir } \\
\text { Model } \\
\text { Pembelajaran } \\
\text { Kooperatif) }\end{array}$ & $\begin{array}{c}\text { (dengan } \\
\text { menggunakan } \\
\text { Model } \\
\text { Pembelajaran } \\
\text { Kooperatif) }\end{array}$ & 0,118 & 0,190 & Normal \\
& & & \\
\hline
\end{tabular}

Berdasarkan tabel atas dapat diketahui bahwa nilai $\mathrm{L}_{\text {tabel }}$ dari daftar $=0,190$. Sedangkan nilai $\mathrm{L}_{\mathrm{O}}$ tes awal sebesar $=0,128$ dan $\mathrm{L}_{\mathrm{O}}$ tes akhir sebesar $=0,118$. Kriteria pengujiannya adalah tolak hipotesisnya nol jika $\mathrm{L}_{\mathrm{O}}$ yang diperoleh dari data pengamatan melebihi $\mathrm{L}_{\text {tabel. }}$. Dalam hal lainnya hipotesis nol diterima. Dengan demikian data tes awal dan tes akhir berdistribusi normal, karena nilai $\mathrm{L}_{\mathrm{O}}$ lebih kecil dari nilai $\mathrm{L}_{\text {tabel. }}$.

Setelah penulis melakukan uji normalitas maka langkah berikutnya penulis melakukan uji homogenitas, ini bertujuan untuk menguji apakan data ini homogen atau tidak. Adapun hasil dari uji homogenitas untuk kelompok 1 adalah sebagai berikut :

Tabel 6. Data Hasil Penghitungan Homogenitas (kesamaan Dua Variansi)

Tes Awal dan Tes Akhir Kelompok 1

\begin{tabular}{|c|c|c|c|c|}
\hline Kelompok & Periode Tes & $\mathbf{F}_{\text {hitung }}$ & $\mathbf{F}_{\text {tabel }}$ & Kesimpulan \\
\hline & $\begin{array}{c}\text { Tes Awal } \\
\text { (tanpa }\end{array}$ & & & \\
Kelompok & $\begin{array}{l} \\
\text { perlakuan) }\end{array}$ & & & \\
(Kelompok & $\begin{array}{c}\text { Tes Akhir } \\
\text { (dengan }\end{array}$ & & & \\
Model & 1,48 & 2,12 & Homogen \\
Pendekatan & $\begin{array}{c}\text { mengunakan } \\
\text { Model }\end{array}$ & & & \\
Taktis) & Pendekatan & & & \\
& Taktis) & & & \\
& & & \\
\end{tabular}


Kriteria pengujian homogenitas adalah terima hipotesis $\mathrm{H}_{\mathrm{O}}$ jika, $\mathrm{F}$ (1- $\left.\alpha\right)$ (m-1) kesamaan dua variansi di atas, diketahui bahwa hasil $\mathrm{F}_{\text {hitung }}=(1,48)$ lebih kecil dari $F_{\text {tabel }}=(2,12)$. Kesimpulan dari hasil pengujian kesamaan dua variansi adalah homogen artinya tidak terdapat perbedaan yang signifikan antara kedua varians tersebut.

Sedangkan hasil dari uji homogenitas untuk kelompok 2 adalah sebagai berikut :

Tabel 7. Data Hasil Penghitungan Homogenitas (kesamaan Dua Variansi)

Tes Awal dan Tes Akhir Kelompok 2

\begin{tabular}{|c|c|c|c|c|}
\hline Kelompok & Periode Tes & $\mathbf{F}_{\text {hitung }}$ & $\mathbf{F}_{\text {tabel }}$ & Kesimpulan \\
\hline & $\begin{array}{c}\text { Tes Awal } \\
\text { (tanpa }\end{array}$ & & & \\
Kelompok 2 & perlakuan) & & & \\
$\begin{array}{c}\text { Kelompok } \\
\text { Model }\end{array}$ & $\begin{array}{c}\text { Tes Akhir } \\
\text { (dengan }\end{array}$ & \multirow{2}{*}{1,07} & 2,12 & Homogen \\
Pembelajaran & $\begin{array}{c}\text { menggunakan } \\
\text { Mooperatif) }\end{array}$ & & & \\
& $\begin{array}{c}\text { Model } \\
\text { Kembelajaran }\end{array}$ & & & \\
& Kooperatif) & & & \\
\hline
\end{tabular}

Kriteria pengujian homogenitas adalah terima hipotesis $\mathrm{H}_{\mathrm{O}}$ jika, $\mathrm{F}(1-\alpha)$ (m-1) kesamaan dua variansi di atas, diketahui bahwa hasil $\mathrm{F}_{\text {hitung }}=(1,07)$ lebih kecil dari $F_{\text {tabel }}=(2,12)$. Kesimpulan dari hasil pengujian kesamaan dua variansi adalah homogen artinya tidak terdapat perbedaan yang signifikan antara kedua varians tersebut.

Langkah selanjutnya adalah melakukan pengujian dan analisis data tes dari hasil tes terhadap sampel (pengujian dan analisis untuk mengetahui apakah terdapat peningkatan hasil waktu aktif yang signifikan dari sampel). Hasil analisis statistika dapat dilihat dibawah ini :

\section{Tabel 8. Data Hasil Pengujian Uji Signifikan Peningkatan Tes Awal dan Tes Akhir}

\begin{tabular}{|c|c|c|c|}
\hline Periode Tes & $\mathbf{t}_{\text {hitung }}$ & $t_{\text {tabel }}$ & Kesimpulan \\
\hline $\begin{array}{l}\text { Tes Awal (tanpa } \\
\text { perlakuan) }\end{array}$ & & & \\
\hline $\begin{array}{l}\text { Tes Akhir (dengan } \\
\text { menggunakan } \\
\text { Model Pendekatan } \\
\text { Taktis) }\end{array}$ & 67,84 & 2,09 & Signifikan \\
\hline
\end{tabular}

peningkatan waktu aktif belajar dilakukan dengan menggunakan uji signifikansi ratarata dua pihak yaitu uji t. Dari hasil pengujian tersebut diperoleh bahwa $t_{\text {hitung }}(67,84)$ lebih besar dari $t_{\text {tabel }}$ pada tingkat kepercayaan atau taraf signifikansi $\alpha=0,05$ dengan $\mathrm{dk}(\mathrm{n} 1-1)=$ 19, harga $\mathrm{t}(0,974)$ dari daftar distribusi $\mathrm{t}$ diperoleh 2,09. Kriteria pengujian adalah, jadi $\mathrm{H}_{\mathrm{O}}$ ditolak. Kesimpulannya adalah model pendekatan taktis memberikan pengaruh yang lebih signifikan dibandingkan dengan model pembelajaran kooperatif terhadap jumlah waktu aktif belajar di SMP Negeri 1 Plered.

- Temuan Hasil Penelitian Pengaruh Model Pendekatan Taktis Terhadap Jumlah Waktu Aktif Belajar Dalam Pembelajaran Permainan Bolabasket Pada Siswa Kelas VIII SMP Negeri 1 Plered Purwakarta.

Dalam pembelajaran permainan bolabasket dengan menggunakan model pendekatan taktis memberikan hasil yang signifikan terhadap jumlah waktu aktif belajar, ini terbukti dengan meninggkatnya aktivitas belajar siswa mulai dari tes awal hingga tes akhir, dimana siswa terlihat lebih aktif dalam pembelajaran dan dapat merasakan kepuasan terhadap pemberian materi yang diberikan guru serta siswa lebih dihadapkan pada situasi dan kondisi permainan bolabasket yang sesungguhnya dan siswa diberikan masalah-masalah taktikal yang harus dipecahkan oleh siswa itu sendiri sampai pada akhirnya siswa dapat memecahkan situasi yang dihadapinya dan dapat memahami materi yang disampaikan guru. Ini sesuai dengan teori menurut Subroto (2001:4) menjelaskan tentang tujuan pendekatan taktis secara spesifik yaitu "untuk meningkatkan kesadaran siswa tentang konsep bermain melalui penerapan teknik yang tepat sesuai dengan masalah atau situasi dalam permainan". Hal ini terlihat dari aktivitas belajar siswa yang sangat antusias dan terlihat lebih aktif bergerak selama pembelajaran permainan bolabasket.

Berdasarkan teori dan data pendukung yang mendasari hasil temuan dalam penelitian ini, dapat disimpulkan bahwa: 
"model pendekatan taktis dapat memberikan pengaruh terhadap jumlah waktu aktif belajar siswa dalam pembelajaran permainan bolabasket."

- Temuan Hasil Penelitian Pengaruh Model Pendekatan Taktis Terhadap Jumlah Waktu Aktif Belajar Dalam Pembelajaran Permainan Bolabasket Pada Siswa Kelas VIII SMP Negeri 1 Plered Purwakarta.

Dalam pembelajaran permainan bolabasket dengan menggunakan model pembelajaran kooperatif memberikan hasil yang signifikan terhadap jumlah waktu aktif belajar, ini terbukti dengan meningkatnya aktivitas belajar siswa mulai dari tes awal hingga tes akhir, ini terlihat dimana siswa secara bersama-sama memecahkan setiap bentuk permasalahan yang diberikan oleh guru, menciptakan kesetiakawanan sosial yang baik, adanya pertukaran informasi dapat meningkatkan wawasan siswa tentang permainan bolabasket yang kesemuanya itu dapat meningkatkan jumlah waktu aktif belajar siswa. Ini sesuai dengan teori menurut Nurhadi (2004) bahwa "keuntungan model kooperatif ini adalah meningkatkan kepekaan dan kesetiakawanan sosial, mengembangkan nilai-nilai sosial, memelihara hubungan saling membutuhkan satu sama lainnya, serta menggunakan ide yang dirasakan lebih baik dalam memecahkan bentuk permasalahan". Artinya bahwa melalui model pembelajaran kooperatif ini siswa dituntut untuk bekerjasama dalam memecahkan setiap bentuk permasalahan yang dihadapi sehingga dalam pelaksanaannya siswa lebih aktif dalam proses pembelajarannya. Hal ini terlihat dari aktivitas belajar siswa dimana siswa bersama-sama memecahkan setiap bentuk permasalahan selama pembelajaran permainan bolabasket.

Berdasarkan teori dan data tersebut, dapat peneliti simpulkan bahwa: "model pembelajaran kooperatif dapat memberikan pengaruh terhadap jumlah waktu aktif belajar siswa dalam pembelajaran permainan bolabasket."

- Temuan Hasil Penelitian Model Pendekatan Taktis Lebih Berpengaruh Dibandingkan Model Pembelajaran Kooperatif Terhadap Jumlah Waktu Aktif Belajar Dalam Pembelajaran Permainan Bolabasket Pada Siswa Kelas VIII SMP Negeri 1 Plered Purwakarta.

Seperti pemaparan diatas, terbukti dimana aktivitas belajar kelompok 1 (kelompok model pendekatan taktis) memperoleh persentase sebesar 75,5\% dibandingkan dengan kelompok 2 (kelompok model pembelajaran kooperatif) yang memperoleh persentase sebesar 65,43\%, sehingga dapat diartikan dengan penerapan model pendekatan taktis, siswa lebih aktif bergerak selama pembelajaran dan siswa sangat antusias terhadap pembelajaran permainan bolabasket karena model ini memberikan kesempatan bergerak selama pembelajaran dan siswa diajak kedalam aktivitas permainan layaknya permainan bolabasket yang sebenarnya.

Menurut Usman (1993:8) menjelaskan bahwa "pembelajaran dikatakan efektif apabila waktu yang digunakan peserta didik selama $75 \%$ s.d $84 \%$ dari total waktu pembelajaran keseluruhan". Target yang ingin dicapai dalam penelitian ini adalah siswa bisa menggunakan waktu belajarnya sesuai dengan teori tersebut, sehingga penulis perlu memberikan suatu treatment agar waktu aktif belajar siswa bisa meningkat. Pemberian treatment ini adalah menerapkan model pendekatan taktis dan model pembelajaran kooperatif di sekolah untuk digunakan pada setiap pembelajaran.

Berdasarkan teori dan data tersebut, dapat peneliti simpulkan bahwa: "model pendekatan taktis memberikan pengaruh yang lebih signifikan dibandingkan dengan model pembelajaran kooperatif terhadap jumlah 
waktu aktif belajar siswa dalam pembelajaran permainan bolabasket."

\section{KESIMPULAN}

Hasil dari penelitian eksperimen ini menyatakan bahwa melalui model pendekatan taktis berpengaruh terhadap jumlah waktu aktif belajar siswa dalam pembelajaran permainan bolabasket di SMP Negeri 1 Plered Purwakarta. Adapun melalui model pembelajaran kooperatif berpengaruh terhadap jumlah waktu aktif belajar siswa dalam pembelajaran permainan bolabasket SMP Negeri 1 Plered Purwakarta.

Berdasarkan hasil analisis data penelitian yang penulis teliti terbukti bahwa model pendekatan taktis memberikan pengaruh yang lebih signifikan dibandingkan dengan model pembelajaran kooperatif terhadap jumlah waktu aktif belajar siswa di SMP Negeri 1 Plered Purwakarta.

\section{DAFTAR PUSTAKA}

Joyce, B. \& Weil, M. dan Calhoun, E. (2009). Models of Teaching: Model-Model Pengajaran. Terjemahan Fawaid,
Ahmad dan Ateilla Mirza. Yogyakarta: Pustaka Pelajar.

Juliantine, T. Subroto, T. \& Yudiana, Y. (2011). Model-model Pembelajaran Pendidikan Jasmani. Bandung : FPOK UPI.

Metzler. (2000). Intructional Models For Physical Education. USA: Allyn and Bacon.

Nurhadi. (2004). Pembelajaran Kontekstual dan Penerapannya Dalam KBK. Malang: UM Press.

Subroto, T. (2001) Pembelajaran Keterampilan dan Konsep Olahraga di Sekolah Dasar. Depdiknas. Jakarta

Sugiyono. (2012). Metode Penelitian Pendidikan Pendekatan Kuantitatif Kualitatif dan R\&D. Bandung : CV Alfabeta.

Suherman, A. (2009). Revitalisasi Pengajaran Dalam Pendidikan Jasmani. Bandung : CV Andira.

Usman, U. (1993). Menjadi Guru Profesional. Bandung : Remaja Rosda Karya.

Winataputra, U. (2001). Model-Model Pembelajaran Inovatif. Jakarta: Depdiknas. 